Economics Development Analysis Journal 6(1)(2017) Economics Development Analysis Journal

\title{
Analysis of Development Strategy of Lasem Batik Small Industry in Rembang (Case Study in Lasem District)
}

Iqlima Fauzia $^{1 凶}$, Rusdarti $^{2}$, Dyah Maya Niahayah ${ }^{3}$

Economics Development Department, Economics Faculty, Universitas Negeri Semarang

\begin{abstract}
Article Info
Article History:

Received October 2017

Accepted December 2017

Published February 2017

Abstract

Batik Lasem Small Industry in Lasem District, Rembang Regency is one of the leading industries in Rembang Regency. The existence of Batik Lasem small industry makes a great contribution to Rembang's income. The problem faced is that the number of demand value is lower than the production value of Batik Lasem, so it shows imbalance in the number of demand of Batik Lasem in Rembang Regency. The purpose of this research is describing the profile of Batik Lasem's

Keywords: Batik Lasem Small Industry, SWOT, Development Strategy entrepreneurs and explaining the internal factors like strength and weakness and also the external factors like opportunity and threat for Batik Lasem small industry in Rembang Regency. The population of this research is 38 entrepreneurs of Batik Lasem small industry in Lasem District, Rembang Regency. The population is taken by using the survey technique. The method of data analysis is descriptive analysis and SWOT analysis. The development strategies of Batik Lasem small industry in Rembang Regency are as follows: the entrepreneurs can enlarge the market share, provide more facilities to the employers in accordance with the needs of production, and also give the training to the entrepreneurs and employers about technology development.
\end{abstract}




\section{INTRODUCTION}

The industrial sector generally grows much more rapidly than the agricultural sector, so it is not surprising if the role of the industrial sector in a country's economy will gradually become more important. Industrial Development aims at obtaining a balanced economic structure among the sectors of industry, agriculture, services and industry as the main drivers of the economic growth and the employment expansion.

Batik is one of the original handicrafts of Indonesia which process of making is usually conducted by people who are experts and usually get the skill of batik painting from generation to generation. Batik handicrafts are widely developed by the small industries and batik is also one of the leading commodities / products / types of business in Central Java. No doubt if batik can become one of the leading commodities in Central Java. There are three relatively large batik clusters in Central Java in Pekalongan city, Surakarta city and Lasem city (Soekesi, 2013). Of the three clusters, Lasem batik industry in Rembang Regency is a cluster which development is not so rapid.

Batik Kricakan was created by Syahdan because of a concern for the work of people who are ordered to break the boulders by Daendels. Batik Lasem continued to incise the gold ink until the end of the Dutch colonial period. Batik Lasem entrepreneurs who came from the Chinese society get a special place in the indigenous population because it opened up a lot of employment. Batik's heyday that became an icon of the assimilation of Javanese and Chinese culture began to recede in the 1950s because it was urged by the rise of batik cap (copper stamp batik) in various regions and because of the arena of political conditions that cornered the ethnic Chinese who is the master of Batik Lasem trade. There were about 140 Batik Lasem entrepreneurs in the 1950s, but the number dropped to a half of the previous number that is 70 people in the 1980s. The peak was in the 1980s, in which Batik Lasem business only had seven people active, then it continued to experience ups and downs, until finally Lasem batik has increased continuously from the production (FEDEP).

The data obtained from the Department of Industry, Trade, Cooperatives and UMKM Rembang shows that the trend of batik business continues to increase. In 2009, the value of batik industry production is 124,194 sheets and the demand value is 98,103 sheets. In 2010 , it has an increase in production to 177,420 sheets and the demand value to 160,279 sheets. In 2011, the production increased to 178,219 sheets and the demand value to 172,510 sheets. In 2012 , the production increased to 182,312 sheets and the demand value to 176,890 sheets. It was continued in 2013 with the production level of Batik Lasem industry of 193,148 sheets while the demand value is 179,260 sheets. But the problem is that the number of demand value is lower than the production value of Batik Lasem. So this shows the gap in the demand for Batik Lasem in Rembang Regency. The problem faced by Batik Lasem Small Industry is that the existence of Batik Lasem is less known by the public because of the constraints on marketing and the limited labor.

Previous Research, citing the Journal of Suliyanto entitled "Development of Local Economy of Batik Tegalan: SWOT Analysis Approach and General Electrics" (2011), this research aims at formulating the development strategy of Batik Tegalan so that it can develop well like batik in Pekalongan City. The result of research is that based on the General Electrics (GE) analysis, it is obtained that the strategic position of Batik Tegalan Industry is to have the middle-classed attraction and the strength of competition that is relatively average, so that the suitable development strategy for Batik Tegalan industry is conducting the identification of the growth segment and conducting the investment selectively. While the development strategy based on the SWOT analysis is as follows: the artisans have a training to produce the varied product, the artisans make a mature production planning so that the production result can be absorbed by the market, the artisans make a wage improvement to the employers in order to increase their motivation, and the artisans 
improve the access to credit by making improvement on the financial statements of business to be more bankable.

Citing the Journal of Arif Murtadlo entitled "Efforts of Business Development of Batik Malangan Artisans " (2013), this research aims at striving for the business development of Batik Malangan artisans so that the artisans can develop well in the development effort of Batik Malangan that is by the implementation of development strategy of the new product. It is known that Indonesia has many batik producing regions, such as Madura, Jogja, Solo, Pekalongan, Banyuwangi, Pacitan, and many others. The development strategy of the new product is expected to make Batik Malangan compete in Indonesian batik market. The research approach used to find and collect the data is a qualitative approach with descriptive research type. The conclusion of this research is as follows: 1 . The development of a business will not be separated from the role of capital. Capital will provide the benefits for a company when utilized as well as possible. The capital includes physical capital, financial capital, human capital, and social capital. 2. Batik Malangan requires efforts to develop in the middle of batik market competition in Indonesia. The efforts undertaken are: implementing the market development strategies aimed at making Batik Malangan more popular in various regions in Indonesia. The next effort is implementing a new product strategy that aims at meeting the consumers' tastes that always change. 3. The consumers' interest in buying batik is not only based on the price factor, but in terms of uniqueness that characterizes Batik Malangan. 4. The development of culture and fashion can positively affect the development of Batik Malangan. Batik has been able to become a popular cultural heritage, a trend, to grow rapidly, be modified, be developed, and be widely spread to become a culture that is never extinct by the times

\section{RESEARCH METHOD}

This research uses descriptive analytical approach with qualitative approach. The descriptive analytical approach with qualitative approach in this research is by giving description about the data or event based on the facts that appear at the situation investigated by the researcher and the object examined separately. The research process is conducted by measurement with the standard tool of SWOT matrix. The type of data used in the research is primary data and secondary data. Methods of Data Collection used in this research are: observation method and questionnaire method.

The process of collecting data is conducted in two ways Observation Method, this technique is conducted by having a survey directly on batik activities in IKM Batik Lasem, especially in Lasem District, Rembang Regency. Using this technique, the writer can see the activity and the process of batik directly.

Questionnaire, from the questionnaire data collecting, the primary data is obtained, in which the data is obtained directly from the respondent. The data is obtained in the form of the respondents' answers to the questions asked based on the questions by answering the questions by writing the answers on the questionnaire sheet and the rating options for the SWOT analysis. In this research the researchers provide questionnaires to be filled by the respondents those are the small industry entrepreneurs of Batik Lasem in Rembang Regency.

\section{RESULTS AND DISCUSSION}

- Batik Lasem Industry is one of the handicraft industry located in Lasem District, Rembang Regency. This industry is very potential because it contributes to absorb the labors and to reduce the number of unemployment. The number of Batik industry entrepreneurs in 2012 was officially 54 people with productivity per month approximately 16 thousand pieces and it absorbed the labor force of 2,119 people.

While in 2013 it rose to 71 entrepreneurs with productivity per month reached 20 thousand pieces and the number of labors absorbed significantly increased to 4,457 people. 
Meanwhile, until the end of 2014 the number of batik entrepreneurs increased to 77 people, with monthly productivity of almost 24 thousand pieces and involved the labors of 4,620 people. Until 2015 the population in Batik Lasem research in Rembang Regency amounted to 77 business units. But the number of population used in this research is only conducted in Lasem District amounted to 38 units of Batik Industry business.

The Factors Affecting the Industrial Development, Small Industry Development, according to Tambunan in Septaria (2011: 24), the development of small industry of a region is affected by several factors those are: (1) industrial location, which can be oriented to various things, like oriented to labor, raw materials, marketing, energy, also technological progress. The basis of the decision orientation is mainly emphasized on the low cost of transportation and labor, (2) the structure of capital and financial management, in which capital in the economic sense includes objects such as land, buildings, machinery, tooling tools and other productive goods for a business activity.

Internal Environment, every effort made always faces the ever changing situation, as experienced by Batik Lasem small industry. Such conditions are not possible without any adjustment process to the existing internal conditions. So, internal environment is the strength or weakness of an organization. (Masiyah, 2003: 33)

The functional sector as the variables in the internal analysis are (David, 2008: 45): a. Capital, b. Raw materials c. Labor force, d. Technology, and e. Marketing.

External Environment, external environment is a condition outside the company that can affect the living conditions of the company. According Viljoen in Khomli (2003: 28), external environment is often referred to as Opportunity and Threat. The analysis of the external environment includes:
1. Economic factors
2. Government's Support
3. Competitors
4. Globalization.

In Rangkuti (2006: 19), SWOT analysis is a systematic identification of various factors to formulate a strategy. This analysis is based on logic that can maximize the strength and opportunity while simultaneously it can minimize the weakness and threat. This is called situational analysis. The most popular model for situational analysis is the SWOT analysis.

Identification of Internal and External Factors, the first stage in the SWOT analysis is to identify the internal and external factors within the local government of Lasem District that are considered to have positive and negative effects in planning and implementing the regional development by benchmarking the external factors of opportunity and threat with the internal factors of strength and weakness, to produce the right analysis. This stage is very important because the results of this identification will be the basis for the subsequent analysis activities.

Based on the result of research, the internal factor of strength in Batik Lasem industry is the availability of the venture capital that has a score of 0.27 . The availability of the raw materials that are easy to obtain has a score of 0.28 . The operating tools in the production process that is very easy with the support of modern tools has a score of 0.22 . The availability of enough labors has a score of 0.25 . The procurement of adequate corporate promotions has a score of 0.26 . In general, the weighted score on the strength aspect is 1.28 . The point of availability of the raw materials easily obtained has the highest weighted score with a value of 0.28 . In conclusion, the raw materials that are easy to obtain is a point of strength for the industry entrepreneur of Batik Lasem, therefore, it will be easier to produce batik if there is no obstacle in the raw materials.

Based on the results of research, the internal factor of weakness of Batik Lasem small industry is the limited capital with the ability to access to the source of weak capital that has a score of 0.16 . The raw material of fabric that is difficult to obtain due to the too far distance has a score of 0.15 . The unstable raw material prices have a score of 0.14 . The unprivileged labor force based on the expertise has a score of 0.17 . The 
production process that is still very traditional has a score of 0.11 . The cheap production making with the low quality has a score of 0.22 . In general, the weighted score on the weakness is 0.95 . And the cheap production making with the low quality has the highest score of 0.22 . So the biggest weakness of Batik Lasem entrepreneurs is making cheap batik with the low quality because the raw material prices are not stable.

Based on the result of research, the external factor of opportunity in Batik Lasem industry is the very strategic business location that has a score of 0.22 . The utilization of science and technology that can be utilized to support the industrial activities has a score of 0.23 . The market share that is still widely opened has a score of 0.28 . The role of government in holding an exhibition to support the superior products entrepreneurs has a score of 0.30 . The role of local government to require the civil servants to use batik on certain days has a score of 0.25 . The benefit of capital loans for business development has a score of 0.31 . The opportunity for free market / globalization has a score of 0.23 . In general, the number of weighting on the aspect of opportunity is 1.82 . The benefit of capital loans for business development has the highest weighting score of 0.31 . In conclusion, Batik Lasem Small Industry is not separated from the capital. The entrepreneurs who easily borrow the capital for the business development provides the opportunities to develop batik business.

Based on the results of research, the external factor of threat to Batik Lasem industry is the existence of similar products from other areas that become the competitors (batik Solo, Pekalongan, Semarang) that has a score of 0.20. The decreasing interest of the public in the purchase of batik painting and they prefer batik printing has a score of 0.25 . The low interest of the public to work in batik painting industry has a score of 0.22 . The local entrepreneurs' understanding about the sale and purchase agreement has a score of 0.14 . The decrease in production in the presence of free trade has a score of 0.19 . In general, the number of weighting on the threat is 1 . The decrease of interest of the public in purchasing batik painting and they prefer batik printing has the highest weighting score of 0.25 . The conclusion can be seen from the highest weight of the biggest threat of Batik Lasem industry that is the existence of batik printing products that are much cheaper than Batik Lasem itself, which can cause a decrease in the consumers' interest in Batik Lasem and become a threat to the small industry entrepreneurs of Batik Lasem.

\begin{tabular}{|l|l|l|}
\hline $\begin{array}{l}\text { I } \\
\text { Growth }\end{array}$ & $\begin{array}{r}\text { II } \\
\text { Growth }\end{array}$ & $\begin{array}{l}\text { III } \\
\text { Shrinkage }\end{array}$ \\
\hline IV & V & $\begin{array}{l}\text { VI } \\
\text { Shrinkage }\end{array}$ \\
\hline Stability & $\begin{array}{l}\text { Growth } \\
\text { Stability }\end{array}$ & IX \\
\hline $\begin{array}{l}\text { VII } \\
\text { Growth }\end{array}$ & $\begin{array}{l}\text { VIII } \\
\text { Growth }\end{array}$ & Liquidation \\
\hline
\end{tabular}

Figure 1. Internal External Matrix

The total score of the internal strength is 1.28 and the weakness is 0.95 . While the total score of the external opportunity is 1.82 and the threat is 1 . From the total score obtained, in which the internal strategic factor is 2.23 and the external strategic factor is 2.82 , shows that the coordinate point lies in the growth area $\mathrm{V}$ as shown in Figure Internal-External Matrix (Rangkuti, 2006: 42). In this case, it means that the problem-solving strategy should concentrate through the horizontal integration.

Based on the SWOT matrix analysis, several strategies can be proposed to develop Batik Lasem Small Industry in Lasem District, Rembang Regency. The first strategy is the SO strategy, which is a strategy that uses the strength to utilize the opportunity in Batik Lasem industry including the role of government to pay attention to Batik Lasem business by providing counseling related to the product development. Besides, it is also by optimizing the management of Batik Lasem industrial development and the product development supported by the presence of 
modern tools to maximize the product, so that it can meet the online market that is more widely spread. The last is the utilization of labors from the location of business to expand the marketing.

The second strategy is the WO strategy that minimizes the weakness to utilize the opportunity. It is the cooperation with institutions for capital loan utilization. Besides it also provides a special training to the entrepreneurs and the employers in accordance with the needs of the product, also provided the modern tools so that the results of production can be improved, and then utilize the market of globalization by developing the production results of entrepreneurs

The third strategy is the ST strategy, which is a strategy that uses the strength to overcome the threat that is optimizing the production results by increasing the competitiveness among Batik Lasem entrepreneurs. Besides, it also provides an understanding of the rules of sales and purchase agreement among the countries. Many of the batik entrepreneurs only know a little of the rules of sales and purchase agreement. In fact, only certain people or the second parties are trading out of the country because they are familiar with the rules and procedures.

The fourth strategy is the WT strategy, which is a strategy that minimizes the weakness and avoids the threat. It is by maintaining the product quality and the product quality and service to the consumers to be better besides increasing the cost efficiency. The biggest threat to Batik Lasem is that the consumers prefer batik printing products which purchase price is more efficient. Therefore, the entrepreneurs must maintain the quality of Batik Lasem still better than other batik. It is possible that the price of batik printing is cheaper but its quality is much less good than the production of Batik Lasem. Therefore, Batik Lasem is identical with batik painting, which is not easily faded and has its own characteristics between China and Java.

\section{CONCLUSION}

Based on the results of research and the discussion, the following conclusions can be drawn:

In Batik Lasem small industry in Lasem District, Rembang Regency, the strength aspect is obtained by an indicator that the easy availability of the raw material has the highest weighted score, while the weakness owned by Batik Lasem entrepreneurs in Lasem District, Rembang is on the indicator that the low cost production with the low quality has the highest score.

The opportunity owned in Batik Lasem small industry in Lasem District, Rembang Regency is that the benefit of capital loan for business development has the highest weighted score, while the threat lies in an indicator that the decreasing interest of public purchasing to batik printing and that they prefer batik printing due to the cheaper price.

The strategy that can be applied to Batik Lasem small industry in Lasem District, Rembang Regency is the concentration strategy through horizontal integration, which means a consolidation which objective is relatively more defensive that is avoiding the loss of sales and the loss of profit. The entrepreneurs in Batik Lasem small industry can expand the market, the production facilities, and the technology through the internal and external development.

\section{REFERENCES}

Akman, Gulsen., Yilmaz, Cengiz. 2008. Innovative Capability, Innovation Strategy And Market Orientation: An Empirical Analysis In Turkish Software Industry. International Journal of Innovation Management. Vol 12 (1)

Anoraga, Pandji dan Sudantoko, Djoko. 2002. Koperasi, Kewirausahaan Dan Usaha Kecil. Jakarta : Rineke Cipta.

Arikunto, Suharsimi. 2002. Prosedur Penelitian Suatu Pendekatan Praktek. Jakarta: PT. Rineke Cipta.

Arumdati.Afra,_2013,

Batik Pedalaman http://ceritakain.wordpress.com, diunduh pada tanggal 9 Desember 2015 
Arsyad, Lincolin. 2004. Ekonomi Pembangunan. Yogyakarta : BPFE.

David,F.R. 2009. Manajemen Strategis. Jakarta: Salemba Empat.

Dwi Asmarani, Asri 2010, Strategi Kebijakan Pembangunan Daerah Kabupaten Klaten: Pendekatan Analisis Swot Dan Ahp, Magister Perencanaan dan Kebijakan Publik UI, Tesis.

Kuncoro, Mudrajad. 2010. Ekonomika Pembangunan : Masalah, Kebijakan, dan Politik. Jakarta: Erlangga.

Loenidou, Leonidas C. 2004. An Analysis of the Barriers Hindering Small Business Export Development. Journal of Small Business Management. Vol 42 (3) pp. 279-302.

Martani, Husein. 1993. Pengembangan Usaha Berskala Kecil di Indonesia. Analisis CSIS No.2

Murtadlo, Arif 2013, upaya pengembangan usaha pengrajin batik malangan, Sarjana Ilmu ekonomi FE Universitas brawijaya, Skripsi.

Rangkuti, Freddy. 2006. Analisis SWOT Teknik Membedah Kasus Bisnis. Jakarta : Gramedia Pustaka Utama.

Rangkuti, Freddy. 2006, Teknik Mengukur dan Strategi Meningkatkan Kepuasan Pelanggan (Measuring Customer Satifaction). Jakarta :Penerbit PT Gramedia Pustaka Utama.

Suliyanto 2011, Pengembangan Ekonomi Lokal Batik Tegalan: Pendekatan Swot Analisis Dan General Electrics, Jurnal ilmu Administrasi Bisnis.

Tambunan, Tulus. 2012. Usaha Mikro Kecil dan Menengah di Indonesia : isu-isu penting. Jakarta: LP3ES

Waits, Mary Jo. 2000. The Added Value of the Industry Cluster Approach to Economic Analysis, Strategy Development, and Service Delivery. Economic Development Quarterly. Vol $14(1)$ 